ББК 63,5

DOI 10.31554/2222-9175-2021-42-69-77

М. М. Содномпилова

ГРОЗОВЫЕ ЯВАЕНИЯ В ТРААИЦИОННОМ МИРОВОЗЗРЕНИИ

И КУАЬТУРЕ ТЮРКО-МОНГОАЬСКИХ НАРОАОВ ВНУТРЕННЕЙ АЗИИ

На территории Внутренней Азии грозовые явления возникают наиболее часто и стали важной частью повседневной жизни ее населения, причиной огромного числа представлений, верований и запретов, легли в основу защищающих обрядов. Центральным в них является образ дракона, менее известные образы громовержцев распространены на периферии Внутренней Азии. Возникновение молнии обосновывается разными причинами (мытье, просушка одежды, пролитие на землю молока, проявление гнева тэнгри по отношению к ряду животных и к злым духам, знак особого расположения Неба к человеку или животному), которые обусловили и разное отношение к поражению молнией человека или животного.

Ключевые слова: Внутренняя Азия, тюрко-монгольские народы, грозовые явления, мифологические образы, шаманизм.

M. M. Sodnompilova

\title{
THUNDERSTORMS IN THE TRADITIONAL WORLDVIEW AND CULTURE OF TURKIC AND MONGOLIAN PEOPLES OF INNER ASIA
}

The territory of Inner Asia is the area where thunderstorms occur most often. These unique meteorological phenomena have become an important part of the daily life of its population, the source of a huge number of ideas, beliefs and prohibitions, which formed the basis of rituals that protect against lightning strikes. The central image is the image of the dragon; lesser-known images of the Thunderers are common on the periphery of Inner Asia. The phenomenon of lightning is substantiated by various reasons (washing, drying clothes, spilling milk on the ground, manifestation of Tengri's anger towards a number of animals and towards evil spirits, a sign of Heaven's special disposition towards a person or animal), which also justified a different attitude towards a person or animal being struck by lightning.

Keywords: Inner Asia, Turkic and Mongolina peoples, thunderstorms, mythological images, shamanism.

\section{Введение}

【астые грозы как характерные черты климата территории Внутренней Азии фиксируются в источниках разного времени, сопровождаясь интересными обоснованиями причин этих явлений. К числу самых ранних источников, в которых, на наш взгляд, просматривается образ страны северных варваров как места, от-

СОДНОМПИЛОВА Марина Михайловна - доктор исторических наук, ведущий научный сотрудник отдела истории, этнологии и социологии Федерального государственного бюджетного учреждения науки Институт монголоведения, буддологии и тибетологии СО РАН (г. Улан-Удэ, Россия). E-mail: sodnompilova@yandex.ru. 
куда слышен шум (гром), падают небесные тела (метеориты), относятся китайские летописи: «История Северной династии Ци», «Ранняя история пяти династий», «Ранняя история Тан», «“Исторические записки” Сыма Цяня». Согласно представлениям китайских летописцев, на севере от Срединного государства расположены огромные равнины и пустыни, куда нисходит Небесная собака (или находится красная собака, называемая Небесной), принося вооруженные смуты, болезни и другие бедствия. Она возвещает о своем приходе страшным грохотом... Люди называют это сошествием Небесной собаки [Де Гроот 2000: 96]. Хотя многогранный образ китайской Небесной собаки [Комиссаров, Кудинова 2012] в большей степени связан с небесными телами - кометами, метеоритами, солнцем и луной, мы полагаем, что один из ее образов, локализуемый на северных равнинах и в пустынях, связан с кочевой культурой, ее культом волка. Образ Красной собаки, нисходящей с громом на равнины, может в определенной степени быть отражением взглядов средневековых китайцев на особенности климатических явлений земли «северных варваров».

В своих трудах Ибн Сина, давая объяснение происхождению небесных предметов (см.: [Юрченко 2007: 25]), упоминает о стране тюрок как месте, где во время гроз и молний падают медные тела в виде наконечников медных стрел с выступом, загнутым вверх.

Метеорологические явления, сопровождающиеся громом и молниями, как особенные явления, присущие огромным степным пространствам кочевников, описываются путешественниками Плано Карпини, Гильомом Рубруком. Плано Карпини отмечает, что «воздух в этой земле распределен удивительно. Именно среди лета, когда в других странах обычно бывает в изобилии наивысшая теплота, там бывают сильные громы и молнии, которые убивают очень многих людей» [Карпини 1997: 32]. В летописи Рашид-ад-Дина уделяется особое внимание стране Могулистан, в которой «холод бывает чрезмерным, а в особенности в той ее части, которую называют Баргуджин-Токум [I]: там непрерывно и последовательно падают молнии» [Рашид-ад-Дин 1952: 157], говорится о разных племенах монголов, для которых частые грозы являются огромным бедствием.

Намного позднее, в начале XX в., частота и сила грозовых явлений в Забайкалье привлекли внимание исследователя Ю. Д. Талько-Грынцевича, который изучал природу нервных заболеваний и физиологических особенностей организма автохтонов Забайкалья, и в частности женщин - казачек, старожилок и семейских. Он считал, что сильные ветры в вечернее и ночное время, летние бури и грозы наводят страх на девушек и женщин, отчего те подвержены беспокойству вплоть до истерики. По его мнению, атмосферные явления Забайкалья предрасполагают женщин к нервным заболеваниям [1903: 99].

Выявление, интерпретация образов и традиций, связанных с грозовыми явлениями, являются целью нашей статьи.

Причины происхождения грозовых явлений в традиционных представлениях

Во взглядах большей части населения Внутренней Азии гром и молнии есть порождение мифического существа - дракона Луу. Этот образ был хорошо известен средневековым монголам, о чем писал Рашид-ад-Дин: «У монголов же считается, что молния исходит от некоего животного, подобного дракону, и в их областях жители будто бы видят своими глазами, как оно падает с неба на землю, бьет по земле хвостом и извивается, а из его пасти извергается пламя... Пользующиеся уваже- 
нием монголы, слова которых заслуживают доверия, касательно этого настойчиво утверждают, что мы де неоднократно видели это сами» [Рашид-ад-Дин 1952: 157].

Согласно этнографическим материалам XIX в., этот образ сохранился у народов Монголии, у бурят Забайкалья, тувинцев. Тувинцы называли небесного дракона Улы-кайракан и верили, что зиму он проводит на вершинах высоких гор, а летом поднимается на небо. «Места его зимовки недоступны; где он зимует, пар стоит» [Потанин 1883: 139]. Образ дракона - «хозяина дождя» в культуре тюрко-монголов Внутренней Азии считается заимствованным [Дугаров 1991: 182; Березкин 2013: 119]. Его предшественниками были иные образы, которые сохранились на периферии региона и нередко сливались в той или иной степени с образом дракона. Так, среди ойратов грозовые явления связывались с белым небесным верблюдом. У монголов и тюрков Южной Сибири громовержцем считался Хайрхан [Бакаева 2003: $73,74]$. Хакасы верили, что молнии являются оружием громовержца Кугурт-хана. «Кугурт-хан являлся хозяином коней-ызыхов белой масти... Шерсть белого ызыха должна напоминать чистоту снега. Кугурт-хан ездил верхом на белом коне-ызыхе, держал в руках чомбур из белых серебряных нитей, был в белой шелковой шапке, в белых сафьяновых сапогах и в таких же перчатках, одежда на нем - из чистого серебра; ... он царь над всеми духами» [Бутанаев, Монгуш 2005: 49]. Тувинцы полагали, что молнии бросает на землю божество Хормусту-Кара-тэнгир. В бурятской мифологии молнии и гром могли исходить от разных небожителей, включая верховного небожителя - Эсэгэ Малан-тэнгри [Потанин 1883: 142], Хөхөдөй-мэргэна (небесного стрелка), Сарь-Саган-тэнгэри Сахилгата будал [Хангалов 1958: 300].

В числе известных со средневековья мнений относительно причин грома и молний, поражающих деревья, людей, животных, жилища, является гнев божеств, который вызывают неправильные действия людей. В монгольском средневековом обществе строго осуждались и даже наказывались некоторые действия, которые могли привести к поражению молнией. К числу таких действий, которые были зафиксированы Плано Карпини, Гильомом де Рубруком, Раши-ад-Дином, относился запрет стирать и сушить одежду в период летних гроз: «Платья свои они не моют и не дают мыть, а особенно в то время, когда начинается гром, до тех пор пока не прекратится это время» [Карпини 1997: 42]; «Платьев они никогда не моют, так как говорят, что Бог тогда гневается и что будет гром, если их повесить сушить. Мало того, они бьют моющих платье и отнимают его у них. Они боятся грома выше меры, высылают тогда чужестранцев из своих домов, закутываются в черные войлоки, в которые прячутся, пока не пройдет гроза» [Рубрук 1997: 99]. Рашид-ад-Дин пишет о племени урянкатов: «Если кто-нибудь снимет с ноги войлочный чулок и захочет высушить его на солнце, то случится та же самая упомянутая беда [молния попадет в дом]. Поэтому, когда они сушат свои войлочные чулки, то закрывают верхушку шатра и сушат их в шатре» [1952: 157].

Другим греховным действием средневековые монголы считали пролитие на землю молока и молочной пищи. О существовании этого запрета у монголов в XIII в. писал Плано Карпини: грехом было «проливать на землю молоко или другой напиток» [1997: 37]. Смысл запрета раскрывает в своей летописи Рашид-адДин: «Если прольется на землю вино или кумыс, молоко пресное и кислое, то молния преимущественно падает на четвероногих, в особенности на лошадей. Если же будет пролито вино, то это произведет еще большее действие и молния наверняка попадет в скотину или в их дом. По этой причине монголы остерегаются делать все это» [1952: 157]. Впоследствии конкретный смысл этого запрета утрачивается и формируется идея об утрате счастья и богатства, образ которого, как правило, воплощался в стадах домашних животных. Так, хакасы верили, что «если молоко 
вылить на землю или в воду, то молочный скот держаться не будет (рассыплется его жизненная сила - хут)» [Бутанаев 1996: 111].

Этнографические материалы XIX в. фиксируют широкое распространение на всей территории Внутренней Азии уже совсем иных представлений: небесные божества стреляют молниями в определенных животных - белку-летягу, бурундука, сову. Кроме того, молнии разят животных и грешных людей, «которые сделали чтонибудь противное небесным кайраканам», а также чертенка (злого духа) [Потанин 1883: 139]. Г. Н. Потанину о грозовых явлениях удалось собрать большой материал на обширной территории северо-западной Монголии, южной Сибири, у бурят Аларской и Тункинской степных дум. По мнению информаторов - тувинцев, алтайцев, халха-монголов, ойратов, бурят, молния бьет именно в то дерево, где скрывается летяга-абырган, бабырган (тюрк.), олби (монг.) или бурундук-корюк (тюрк.), жирх (монг.) [II]. По мнению тункинских бурят, «олбо - злой дух, которого тэнгри хочет убить молнией. Олбо во время грома сердится и становится большой, с котел величиной» [Потанин 1893: 142]. Причина, по которой небо гневается на этих зверьков, большинству информаторов была мало понятна, были распространены мнения, что эти животные «сделали что-то неприятное Небу», «бурундук украл у неба корову», летяга «сделала что-то худое сыну Неба», «тэнгри мстит ему [летяге] за то, что он выкопал глаза младшему сыну Неба» [Там же: 140, 141, 181], «ольби, летяга превозносится перед небом и, поместившись под деревом, раздувается с корову...» [Там же: 343]. Исходным мифологическим сюжетом, к которому привязаны все эти объяснения, вероятно, является алтайский миф о Дьайыке [Ойноткинова 2019]. Страхом летяги перед молнией объясняется даже образ жизни этого зверька, который показывается людям только зимой [Потанин 1883: 181].

Чтобы сделать приятное небесному божеству и заслужить его милость, многие информаторы считали полезным убивать бурундука или летягу: дархаты сжигали зверька и его пепел развеивали по воздуху, алтайцы убивали бурундука и бросали, алтайские охотники перед охотой приносили летягу в жертву небесному божеству.

Халха-монголы летом опасались иметь в доме шкурку бурундука, считали, что в дом может попасть молния. Во время дождей и гроз они избегали также бродить в лесу, где много бурундуков. Верили, что молния бьет именно в бурундука [Арьясурэн, Нямбуу 1992: 516].

Вместе с тем существовали и совершенно противоположные мнения и действия, особенно в тех местах, куда эти взгляды доходили в трансформированном виде. «Алтайцы считают за грех убивать летягу (абыргань); кто убьет, тому будет худо»; ордосские монголы, наоборот, считали полезным держать в доме бурундука, солонго, якобы они оберегают дом от непогоды [Потанин 1893: 343]. В доме закаменских бурят нам довелось увидеть шкурку белки-летяги, натянутую на палочки и закрепленную на стене. Информатор-охотник объяснил, что он точно не знает назначение шкурки, но, как «говорят люди, шкурка этого зверька предохраняет дом от несчастья» [ПМА 1].

Многие верили, что небесное божество стреляет молниевыми стрелами в злых духов, чертей. Они могли прятаться где угодно, включая и жилище человека. В этой связи у хакасов возник особый ритуал очищения дома при раскатах первой в новом году грозы. «Гром разгонял чертей и очищал от них землю. При первом весеннем громе все домашние выскакивали на улицу, двери открывали настежь. Помещение освобождали от всех животных, включая собак и кошек. Хозяйка, зачерпнув ковшом айран, обегала три раза по солнцу юрту, стучала по каждому звену решетки ковшом и со словами арабского происхождения «элем-салам, т. е. мир над вами», кропила айраном на все стороны, остальные домочадцы, опалив на огне до черно- 
ты края черемухового прута или взяв кочергу, садились на них верхом и по солнцу обегали три раза юрту, опоясывая ее невидимым огнем. Подобные действия были направлены против злых сил, которые пугались огненной стихии... » [Бутанаев, Монгуш 2005: 49].

\section{Время гроз в календарной системе тюрко-монголов}

Время первой грозы было особенным, сакральным в кочевой культуре и занимало важное место в календаре кочевников и ритуальной практике. Первые громовые раскаты, так же как первые звуки кукушки, отождествлялись саянскими тюрками с наступлением Нового года. Тувинцы, после того как в небе отгремели раскаты первого весеннего грома, выходили из юрты, налив молоко в деревянное ведро, и хозяйка разбрызгивала молоко туда, где гремело небо, обходила юрту по солнцу три раза и благословляла: «Владыка! Пришло начало года, змеиная кожа облезла, Владыка!» [Там же: 49]. «Алтайцы приносят жертву огню после первого грома. При этом колют рыжеголового барана» [Потанин 1883: 89]. Урянхайцы во время грома, делая возлияние молоком, произносят: «Эдзень-сульдэ!» [Он же 1893: 340]. Монголы также считают начало лета, когда гремит гром, благоприятным временем. Домохозяева облачаются в нарядную одежду, кладут в чаши простоквашу, молоко и, обходя дом по солнцу, совершают подношение небу и земле, окропляют жилище, приговаривая при этом: «Зудаа цааш нь, зунаа нааш нь» (Беда от нас, лето к нам). Так же как саянские тюрки, ценившие щепки дерева, разбитого молнией, монголы держали дома ветки деревьев и кустарников, которые якобы защищали дом от молний, и даже изготавливали из них части юрты. К таким деревьям относили березу, белый саксаул. В летнее время во избежание поражения молнией в каждой семье хранили кость животного, убитого молнией, ветку саксаула, камень, способный влиять на погоду задын чулуу, буддийскую молитвенную книгу «Алтангэрэл» [Арьясурэн, Нямбуу 1992: 528]. В ритуале западных монголов во время первой грозы присутствовал обряд раскладывания вне юрты жертвенных даров - заколотого барана и 27 видов белой молочной пищи. Молоком обмывали юрту с помощью ритуальной деревянной ложки - цุацал с девятью углублениями. Ритуал очищения жилища и имущества молоком во время грозы, который якобы «уводил» грозу в другое место, исполнялся монголами и в XX в. [Галданова 1987: 19].

Белый цвет предметов (белые одежды, белый войлок, белая пища), адресованных небу во время грозы, Г. Р. Галданова относит к символам солнца, атрибутами которого были молнии [Там же]. Возможно, что в традиции во время первой летней грозы надевать нарядные белые одежды и совершать обряд жертвоприношения небу и земле молочной пищей во избежание поражения молнией людей, животных и жилищ отражаются отголоски воззрений о связи нового временного цикла с первой грозой. В пользу этого предположения говорит и следующий факт: с первой грозой в традиции тюрко-монгольских народов Внутренней Азии были связаны гадания, которые обычно сопутствуют новогодним праздникам. Когда звучал первый гром, внимательно прислушивались, в какой стороне он гремит. Хакасы считали, что если гром прогремит с южной стороны, то в это лето будут молочными кобылицы, если с северной - коровы, с восточной - овцы, с западной - собаки [Бутанаев, Монгуш 2005: 49]. Сходное толкование примет, связанных с первым громом, записал Г. Н. Потанин на Алтае: «Когда первый гром гремит, примечают, с какой стороны в юрте его слышно: если с женской - будет хороший удой молока, с мужской - прибыль в звере и т. п.» [1883: 142]. Скорее всего неточностью отличается запись, сделанная М. Н. Хангаловым у унгинских бурят по поводу первого грома: «По словам 
унгинских бурят, если первый весенний гром бывает на северо-западной стороне, то кобылы будут молочными в это лето, а если первый весенний гром будет на северовосточной стороне, то коровы не будут молочными в это лето» [Хангалов 1959: 225]. В день первой грозы у неба также просили изобилия молока и увеличения стад. Саянские тюрки произносили заклинания: «Я услышал раскаты первого грома! Пусть я буду богатым! Пусть мои коровы станут стельными, а двор наполнится скотом!» [Бутанаев, Монгуш 2005: 49]. Подобные просьбы также соответствуют формату новогодних традиций.

\section{Поражение молнией}

Поражение молнией человека или животного в культуре саянских тюрков и бурят XIX-XX вв. рассматривалось как знак особого внимания Неба, в противоположность взглядам халха-монголов, которые расценивали поражение молнией как несчастье [Потанин 1883: 140-141]. Хоронить в земле жертвы молний запрещалось, их размещали на специальном помосте - аранга. В бурятском шаманизме пораженный молнией человек считался избранником Неба, а его потомки получали особые ymxa - способности шаманить, дарованные Небом. «Убитый громом человек считается за какие-нибудь выдающиеся качества взятым на Небо, к божествам грома и молнии, почитается наравне с умершими шаманами, а потомство его получает шаманское утха - будал утха, право быть шаманом» [Михайлов 1996: 16]. В XX в. это убеждение получило новое развитие: в век электрической энергии с ударом молнией стало сопоставимо поражение электрическим током. Один из наших информаторов, электрик по специальности и практикующий шаман, сообщил, что учиться искусству шаманских практик он стал довольно поздно, после того как его ударило сильным разрядом тока во время ремонта высоковольтных сетей. Ему повезло, он остался жив, а его окружающие и знакомые шаманы посчитали это событие своеобразным посвящением в шаманы, признав, что удар молнии сопоставим с поражением электрического тока большой силы [ПМА 2].

\section{Заключение}

Грозовые явления в традиционном мировоззрении тюрко-монгольских народов Внутренней Азии отражены в разных образах. Наиболее известен образ Небесного дракона, менее известные образы громовержцев распространены на периферии Внутренней Азии. Явление молнии обосновывается разными причинами, среди которых наиболее архаичные и утратившие актуальность мытье, просушка одежды; пролитие на землю молока. Более поздними являются верования, что молния - это проявление гнева тэнгри по отношению к ряду животных - бурундуку, летяге, сове и к злым духам в целом. Исходный сюжет о животных как причине молний, вероятно, связан с алтайскими мифами. Формируя представления, особые ритуалы, версии этого сюжета распространились очень широко в Южной Сибири, Западной Монголии, у тункинских и аларских бурят. В то же время существовали и иные взгляды на природу молнии - ее рассматривали как знак особого расположения к человеку или животному.

Публикация выполнена в рамках государственного задания Министерства образования и науки России (проект «Россия и Внутренняя Азия: динамика геополитического, соииально-экономического и межкультурного взаимодействия (XVII-XXI вв.)») № 121031000243-5. 


\section{Примечание}

I. О территории Баргуджин-Токум см. подробно: [Нанзатов 2018].

II. Данные термины известны только в ареале обитания этих животных. На территории Внутренней Азии ареал обитания, в частности белки-летяги, ограничен и касается только северных территорий региона, поскольку зверьки предпочитают влажные лиственные леса - березняки, ольшаники. Термин olbi в монгольских языках, по мнению А. А. Бурыкина, а конкретно его дублетная форма $o b$ является старым тюркизмом, при том что в тюркских языках со временем данный термин исчез. Более того, А. А. Бурыкин видит в этом примере отражение паратюркского и парамонгольского языковых состояний и свидетельство алтайского языкового родства [2013: 33-34].

\section{Информанты:}

1. Жалсанов Д. Б., 1923 г. р., хонгодор, с. Цаган-Морин Закаменского р-на Республики Бурятия (2004 г.).

2. Басхаев Г. В., 1931 г. р., буура, Эхирит-Булагатский район, с. Байтог (2003 г.).

\section{\итература}

Бакаева Э. П. Добуддийские верования калмыков / Э. П. Бакаева. - Элиста: Джангар, 2003. $-358 \mathrm{c}$.

Березкин Ю. Е. Африка, миграции, мифология / Ареалы распространения фольклорных мотивов в исторической перспективе / Ю. Е. Березкин. - СПб.: Наука, 2013. - 320 с.

Бурыкин A. A. О некоторых названиях диких животных в тюркских языках (к этимологии изолированной лексики и оценке характера эволюции тюркских языков в контексте алтайской теории) / А. А. Бурыкин // Российская тюркология. - 2013. - № 1(8). - С. 31-36.

Бутанаев В. Я. Традиционная культура и быт хакасов / В. Я. Бутанаев. - Абакан: Хакас. кн. изд-во, 1996. -224 с.

Бутанаев В. Я. Бурханизм тюрков Саяно-Алтая / В. Я. Бутанаев. - Абакан: Изд-во Хакас. гос. ун-та, 2003. -259 с.

Бутанаев В. Я. Архаические обычаи и обряды саянских тюрков / В. Я. Бутанаев, Ч. В. Монгуш. - Абакан: Изд-во Хакас. гос. ун-та, 2005. - 197 с.

Галданова Г. Р. Доламаистские верования бурят / Г. Р. Галданова. - Новосибирск: Наука, 1987. - $114 \mathrm{c}$.

Дугаров Д. С. Исторические корни белого шаманства (на материале обрядового фольклора бурят) / Д. С. Дугаров. - М.: Наука, 1991. - 300 с.

Де Гроот Я. Я. М. Демонология Древнего Китая / Я. Я. М. де Гроот. - СПб.: Евразия, 2000. -352 c.

Карпини Плано Дж. дель. История монгалов / Дж. дель Плано Карпини // Путешествие в восточные страны / пер. И. М. Минаева. - М.: Мысль, 1997. - С. $28-85$.

Комиссаров C. А. Образ Небесного пса в китайской мифологии / С. А. Комиссаров, М. А. Кудинова // Вестник Новосибирского государственного университета. Сер. История, филология. - 2012. - Т. 11. - № 4. - С. 70-79. $110 \mathrm{c}$.

Михайлов В. А. Религиозная мифология / В. А. Михайлов. - Улан-Удэ: Соёл, 1996. -

Нанзатов Б. 3. Интерпретация значения Баргуджин-токум: древнетюркские корни / Б. 3. Нанзатов // Тюркологический сборник. 2015-2016: Тюркский мир Евразии / ред. кол. Т. Д. Скрынникова, Т. И. Султанов, И. В. Зайцев. - М.: Наука; Вост. лит-ра, 2018. - С. $263-$ 275.

Ойноткинова Н. Р. Обряд освящения покровителя семьи - Дьяйык (Јайык). Этнографические описание / Н. Р. Ойноткинова // Обрядность в традиционной культуре алтайцев. - Горно-Алтайск, 2019. - С. 74-77.

Потанин Г. Н. Очерки Северо-Западной Монголии. Вып. IV: Материалы этнографические / Г. Н. Потанин. - СПб.: Тип. В. Киршбаума, 1883. - 1029 с. 
Потанин Г. Н. Тангутско-тибетская окраина Китая и Центральная Монголия. Путешествие Потанина. 1884-1886. Т. 2 / Г. Н. Потанин. - СПб.: Типогр. Суворина, 1893. - 437 с.

Рашид-ад-Дин. Собрание летописей / Рашид-ад-Дин. Т. 1. Кн. 1. - Л.; М.: Изд-во АН CCCP, 1952. $-221 \mathrm{c}$.

Рубрук Г. де. Путешествие в восточные страны / Г. де Рубрук // Путешествие в Восточные страны / пер. И. М. Минаева. - М.: Мысль, 1997. - С. 86-189.

Талько-Грынцевич Ю. Д. К вопросу об изучении физиологических явлений половой жизни женщин в Забайкалье / Ю. Д. Талько-Грынцевич // Труды Троицкосавско-Кяхтинского отделения Приамурского отдела Императ. Русского географического общества. - 1903. - T. VI. - Вып. 1. - С. 95-135.

Хангалов М. Н. Собрание сочинений / М. Н. Хангалов. Т. І. - Улан-Удэ: Бурят. кн. изд-во, 1958. - 550 с.

Хангалов М. Н. Собрание сочинений: в 3 т. Т. ІІ. - Улан-Удэ: Бурят. кн. изд-во, 1959. $443 \mathrm{c}$.

Хангалов М. Н. Собрание сочинений / М. Н. Хангалов. Т. ІІІ. - Улан-Удэ: Бурят. кн. изд-во, 1960. $-420 \mathrm{c.}$

Юрченко А. Г. Книга камней. Чудеса мира в восточных космографиях / А. Г. Юрченко. - СПб.: Евразия, 2007. - 256 с.

Арьясурэн Ч. Монгол ёс заншлын их тайлбар толь. Тэргуун боть / Ч. Арьясурэн, Х. Нямбуу. - Улаанбаатар: Суулэнхуу, 1992. - 928 х.

\section{References}

Bakaeva E. P. Dobuddijskie verovaniya kalmykov / E. P. Bakaeva. - Elista: Dzhangar, 2003. $-358 \mathrm{~s}$.

Berezkin Yu. E. Afrika, migracii, mifologiya / Arealy rasprostraneniya fol'klornyh motivov $\mathrm{v}$ istoricheskoj perspektive / Yu. E. Berezkin. - SPb.: Nauka, 2013. - 320 s.

Burykin A. A. O nekotoryh nazvaniyah dikih zhivotnyh v tyurkskih yazykah (k etimologii izolirovannoj leksiki i ocenke haraktera evolyucii tyurkskih yazykov v kontekste altajskoj teorii) / A. A. Burykin // Rossijskaya tyurkologiya. - 2013. - № 1(8). - S. 31-36.

Butanaev V. Ya. Tradicionnaya kul'tura i byt hakasov / V. Ya. Butanaev. - Abakan: Hakas. kn. izd-vo, 1996. - $224 \mathrm{~s}$.

Butanaev V. Ya. Burhanizm tyurkov Sayano-Altaya / V. Ya. Butanaev. - Abakan: Izd-vo Hakas. gos. un-ta, 2003. - 259 s.

Butanaev V. Ya. Arhaicheskie obychai i obryady sayanskih tyurkov / V. Ya. Butanaev, Ch. V. Mongush. - Abakan: Izd-vo Hakas. gos. un-ta, 2005. - 197 s.

Galdanova G. R. Dolamaistskie verovaniya buryat / G. R. Galdanova. - Novosibirsk: Nauka, 1987. - $114 \mathrm{~s}$.

Dugarov D. S. Istoricheskie korni belogo shamanstva (na materiale obryadovogo fol'klora buryat) / D. S. Dugarov. - M.: Nauka, 1991. - 300 s.

De Groot Ya. Ya. M. Demonologiya Drevnego Kitaya / Ya. Ya. M. de Groot. - SPb.: Evraziya, 2000. - $352 \mathrm{~s}$.

Karpini Plano Dzh. del'. Istoriya mongalov / Dzh. del' Plano Karpini // Puteshestvie v vostochnye strany / per. I. M. Minaeva. - M.: Mysl', 1997. - S. 28-85.

Komissarov S. A. Obraz Nebesnogo psa v kitajskoj mifologii / S. A. Komissarov, M. A. Kudinova // Vestnik Novosibirskogo gosudarstvennogo universiteta. Ser. Istoriya, filologiya. - 2012. - T. 11. - № 4. - S. 70-79.

Mihajlov V. A. Religioznaya mifologiya / V. A. Mihajlov. - Ulan-Ude: Soyol, 1996. - $110 \mathrm{~s}$.

Nanzatov B. Z. Interpretaciya znacheniya Bargudzhin-tokum: drevnetyurkskie korni / B. Z. Nanzatov // Tyurkologicheskij sbornik. 2015-2016: Tyurkskij mir Evrazii / red. kol. T. D. Skrynnikova, T. I. Sultanov, I. V. Zajcev. - M.: Nauka; Vost. lit-ra, 2018. - S. 263-275.

Ojnotkinova N. R. Obryad osvyashcheniya pokrovitelya sem'i - D'yajyk (Jajyk). Etnograficheskie opisanie / N. R. Ojnotkinova // Obryadnost' v tradicionnoj kul'ture altajcev. - GornoAltajsk, 2019. - S. 74-77. 
Potanin G. N. Ocherki Severo-Zapadnoj Mongolii. Vyp. IV: Materialy etnograficheskie / G. N. Potanin. - SPb.: Tip. V. Kirshbauma, 1883. - 1029 s.

Potanin G. N. Tangutsko-tibetskaya okraina Kitaya i Central'naya Mongoliya. Puteshestvie Potanina. 1884-1886. T. 2 / G. N. Potanin. - SPb.: Tipogr. Suvorina, 1893. - 437 s.

Rashid-ad-Din. Sobranie letopisej / Rashid-ad-Din. T. 1. Kn. 1. - L.; M.: Izd-vo AN SSSR, 1952. $-221 \mathrm{~s}$.

Rubruk G. de. Puteshestvie v vostochnye strany / G. de Rubruk // Puteshestvie v Vostochnye strany / per. I. M. Minaeva. - M.: Mysl', 1997. - S. 86-189.

Tal'ko-Gryncevich Yu. D. K voprosu ob izuchenii fiziologicheskih yavlenij polovoj zhizni zhenshchin v Zabajkal'e / Yu. D. Tal'ko-Gryncevich // Trudy Troickosavsko-Kyahtinskogo otdeleniya Priamurskogo otdela Imperat. Russkogo geograficheskogo obshchestva. - 1903. - T. VI. - Vyp. 1. - S. 95-135.

Hangalov M. N. Sobranie sochinenij / M. N. Hangalov. T. I. - Ulan-Ude: Buryat. kn. izd-vo, 1958. $-550 \mathrm{~s}$. $443 \mathrm{~s}$.

Hangalov M. N. Sobranie sochinenij: v 3 t. T. II. - Ulan-Ude: Buryat. kn. izd-vo, 1959. -

Hangalov M. N. Sobranie sochinenij / M. N. Hangalov. T. III. - Ulan-Ude: Buryat. kn. izd-vo, 1960. $-420 \mathrm{~s}$.

Yurchenko A. G. Kniga kamnej. Chudesa mira v vostochnyh kosmografiyah / A. G. Yurchenko. - SPb.: Evraziya, 2007. - 256 s.

Ar'yasuren Ch. Mongol yos zanshlyn ih tajlbar tol'. Terguun bot' / Ch. Ar'yasuren, H. Nyambuu. - Ulaanbaatar: Suulenhuu, 1992. -928 h. 